\title{
SOME CASES OF NEGATIVE EXTERNALITIES IN THE TIRANA AREA AND THEIR IMPACT ON SOCIAL COSTS
}

Eglantina Pazaj

Agricultural University of Tirana; Department of Economics and Rural Development Policies, Tirana, Albania;

"Corresponding author: Eglantina Pazaj, email: epazaj@ubt.edu.al;

Received May, 2018; Accepted June, 2018; Published July, 2018;

DOI: https://doi.org/10.31407/ijees8403

UOI license: http://u-o-i.org/1.01/ijees/58089975

\begin{abstract}
One of the main problems of Albanian society today is pollution of the environment and mainly pollution of air, soil, water, acoustic pollution and radioactive pollution. This problem feels very much to all residents of the district of Tirana. Causes or factors of environmental pollution are many. Our focus will mainly be on air and soil pollution. Such can be mentioned as pollution from cars, pollution from factories, pollution from plastic wastes, and especially pollution from individuals themselves. All of these factors that cause environmental pollution are called as negative externalities because the impacts of their actions affect the well-being of a contemplative. Negative externalities make the markets distribute resources in an inefficient way. How will social and private costs change in the presence of a negative externality? In this topic we will try to address some cases of negative externalities and we will try to give some of their solutions through private actors but also through the intervention that the government can do through different policies. We will try to answer the following questions: What are the consequences of pollution in society? Does the pollution of the environment cost you and on what does it render? What is our role in society to minimize pollution?, etc. Finding a solution to the elimination of externalities would affect the improvement of market failure.
\end{abstract}

Key words: environmental pollution, negative externality, social and private costs, political. 